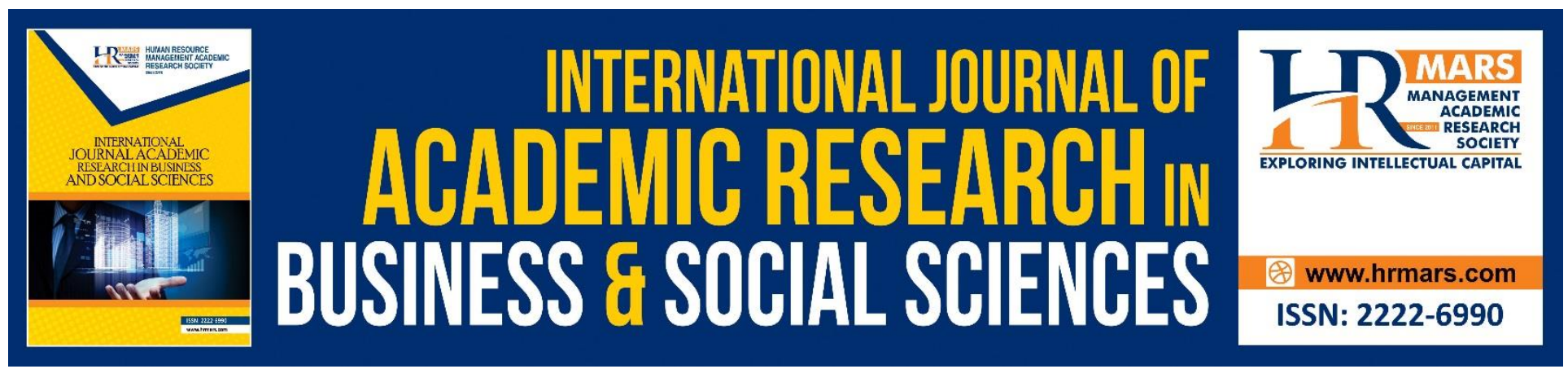

\title{
The Ultimate Objective of Islamic Based Development: an Analysis of the Views of Experts
}

Kamarul Ariffin Ithnan, Mohd Syakir Mohd Rosdi

To Link this Article: http://dx.doi.org/10.6007/IJARBSS/v8-i10/4724

DOI: $10.6007 /$ IJARBSS/v8-i10/4724

Received: 28 Sept 2018, Revised: 22 Oct 2018, Accepted: 26 Oct 2018

Published Online: 30 October 2018

In-Text Citation: (Ithnan \& Rosdi, 2018)

To Cite this Article: Ithnan, K. A., \& Rosdi, M. S. M. (2018). The Ultimate Objective of Islamic Based Development: an Analysis of the Views of Experts. International Journal of Academic Research in Business and Social Sciences, 8(10), 191-201.

Copyright: (C) 2018 The Author(s)

Published by Human Resource Management Academic Research Society (www.hrmars.com)

This article is published under the Creative Commons Attribution (CC BY 4.0) license. Anyone may reproduce, distribute, translate and create derivative works of this article (for both commercial and non-commercial purposes), subject to full attribution to the original publication and authors. The full terms of this license may be seen

at: http://creativecommons.org/licences/by/4.0/legalcode

Vol. 8, No. 10, 2018, Pg. 191 - 201

http://hrmars.com/index.php/pages/detail/IJARBSS

JOURNAL HOMEPAGE

Full Terms \& Conditions of access and use can be found at http://hrmars.com/index.php/pages/detail/publication-ethics 


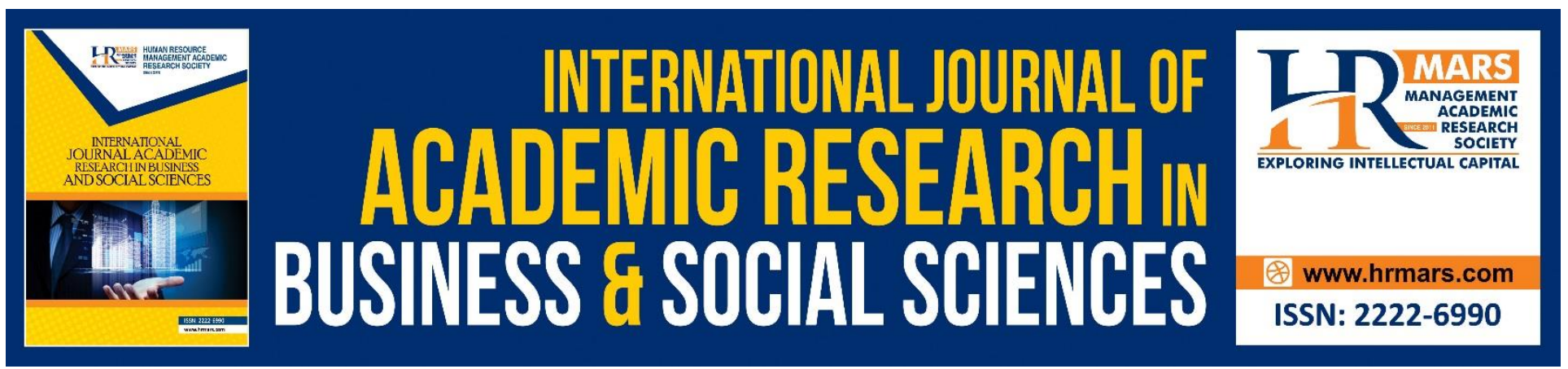

\title{
The Ultimate Objective of Islamic Based Development: an Analysis of the Views of Experts
}

\author{
Kamarul Ariffin Ithnan ${ }^{1}$, Mohd Syakir Mohd Rosdi ${ }^{2}$ \\ ${ }^{12}$ The Centre for Islamic Development Management Studies (ISDEV), Universiti Sains Malaysia, \\ Pulau Pinang \\ Email: 1ithos_member@yahoo.com/2*mohdsyakirmohdrosdi@gamil.com
}

\begin{abstract}
This article aims to examine and study the ultimate objective of Islamic based development (IBD) based on the views of experts. There were various discussions on the ultimate objective of IBD among the experts on IBD. Some stated that the ultimate objective is al-falah (victory in this world and the hereafter), and some stated that it is mardat Allah (the pleasure of Allah). The question is, what is the true ultimate objective of IBD? In order to answer this question, this article focused the discussion to two main subjects. Firstly, to identify the views of IBD experts on the ultimate objective of IBD. Secondly, to analyse and summarize the ultimate objective of IBD based on the views of experts. This qualitative study utilized secondary data from studies and articles regarding the ultimate objective of IBD. All of these data were analysed using the method of content analysis. In conclusion, it was found that the ultimate objective of IBD is to attain mardat Allah (the pleasure of Allah SWT), not al-falah. Keywords: Ultimate Objective, Islamic Based Development, Expert, Al-Falah, Mardat Allah
\end{abstract}

\section{INTRODUCTION}

This article aims to identify and analyse the ultimate objective of Islamic based development (IBD). The true ultimate objective is of utmost importance in IBD. This is because the objective of IBD is different than common development (CD). Other than prioritizing only on the benefits in this world, $C D$ appears to neglect religious values because the theory in $C D$ considered religion as a tool for development instead of vice versa (Todaro, 1977). The objective of IBD is very different as it encompasses both this world and the hereafter (Salleh, 2009 \& 2008a).

From another perspective, studies regarding the ultimate objective of IBD should be performed as there were various discussions on the ultimate objective of IBD by experts on IBD. According to some, al-falah (victory in this world and the hereafter) is the ultimate objective of IBD. What is the true ultimate objective of IBD? In order to answer this question, this article offered two aims. Firstly, to identify the ultimate objective of IBD based on the views of IBD experts. Secondly, to analyse and 
INTERNATIONAL JOURNAL OF ACADEMIC RESEARCH IN BUSINESS AND SOCIAL SCIENCES Vol. 8, No. 10, Oct. 2018, E-ISSN: 2222-6990 @ 2018 HRMARS

summarize the true ultimate objective of IBD. Based on these two objective, the discussion in this article are divided into three parts. Firstly, the ultimate objective; secondly, Islamic based development, and thirdly, the analysis of both subjects.

\title{
ULTIMATE OBJECTIVE ${ }^{1}$
}

In Arabic, ultimate objective is phrased as al-ghayat al-'aliyyat. Al-ghayat means flag, while al-'aliyyat is height (Munawwar, 1984). Al-ghayat al-'aliyyat here can be translated to matlamat akhir (ultimate objective) in Malay. While matlamat (objective) is defined in Kamus Komprehensif Bahasa Melayu as sasaran (aim) (Othman, 2005). In Kamus Arab-Melayu, al-ghayat means tujuan, matlamat and sasaran (purpose, objective, and aim) (Hasan, 2011).

There are various definition of ultimate objective by development scholars. According to Ahmad (2008), the role and life goal of a Muslim in this world is self-devotion in the form of unwavering worship to Allah SWT. In 15 articles written by Pendeta Za'ba (Zainal Abidin, 1989), among others, he stated that the ultimate objective of a human being as the servant of Allah SWT is to achieve victory. He stated that life in this world is a life of practice and work. A life of struggle and competition as in a race. A person has to strive without expecting help from others in attaining success. In the meantime the ultimate goal of the world Zionist organization is to create a New World Order centralized on One World Government (Gray: 2013). However, the ultimate objective in this research refers to the ultimate objective of IBD.

\section{THE ULTIMATE OBJECTIVE OF ISLAMIC BASED DEVELOPMENT}

In order to implement the IBD, the objective aspect is to be emphasized. This is because the success in IBD whether in material or spiritual development, is very different from CD. For example, CD associates development with quantitative measures and economic upgrades as a decisive factor, contrary to IBD that does not measure development based on quantitative measures and economic improvements are not the determinants of everything. The objective of IBD is vastly different, encompassing both this world and the hereafter (Salleh, 2009\& 2008a). This fact is explained in a Hadith:

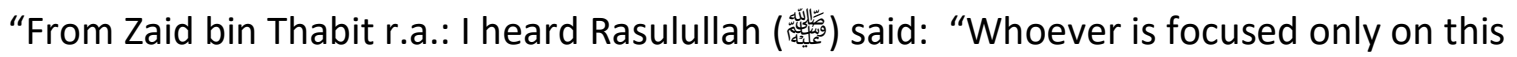
world, Allah will confound his affairs and make him fear poverty constantly, and he will not get anything of this world except that which has been decreed for him. Whoever is focused on the Hereafter, Allah will settle his affairs for him and make him feel content
\end{abstract}

\footnotetext{
${ }^{1}$ For a materialist, his life is based on materialistic ideology, and a socialist emphasizes social concepts in community. While a capitalist tries to attain maximum benefits from a self-constructed system. Each individual or community has their own objective and purpose. Unfortunately, the goals and objectives have been misled and misinterpreted due to the desire and pursuit of worldly life. They think that knowledge is capable of conquering people, the world and whatever they desire. On the other hand, the supporters of secularism view that religion and worldly life are something that needs to be separated. For them, all forms of religious beliefs that lead to obedience to Allah SWT and preserving the limits of Shariah are limited to personal practices only, while general matters involving human life as a whole must be overcome purely with material strength (Idris, 1996:13).
} 
with his lost, and his provision and worldly gains will undoubtedly come to him" (Riwayat Ibn Majah: 2726, no. hadith 4105).

From the above hadith, it can be understood that the ultimate goal of such development must provide the ultimate success and happiness both in the world and in the hereafter. This will only be achieved if the al-ghayat (objective) of the development can be appreciated and implemented correctly.

In the meantime, various parties have discussed the ultimate objective of IBD. The most dominant discussions on ultimate objective of development can be divided into two groups of thought. The first group stated that the ultimate objective of IBD is al-falah while the second group argued that mardat Allah is the ultimate objective of IBD. The discussion on the differences of these two streams of thought is described in subtopics (a) and (b).

\section{(a) Group that says al-Falah}

Among the development scholars that stated al-falah as the objective of IBD are Ahmad (1994), Salamon (2009:2), Hassan (2014), Hunter (2012)² and Chapra (1995).

According to Ahmad (1994:20), the ultimate objective of IBD is al-falah. This is clarified in his quote:

"The Islamic concept of development follows from its concept of tazkiyah, as it addresses itself to the problem of human development in all its dimensions: development is concerned with growth towards perfection through purification of attitudes and relationships. The result of tazkiyah is falah - prosperity in this world and the hereafter."

This is supported by the opinion of Salamon (2009:2). He said:

"Humans are expected to be able to perform their duties as a caliph of Allah on earth well because this responsibility will be accounted for in the hereafter. It is for this reason that the success of every Muslim individual in implementing the demands of economic life is to achieve al-falah, the real success in the world and the hereafter."

According to Hassan (2014), the general principles of implementing IBD include social justice, principles of work and rewards, the principle of avoiding from wrongdoings and appreciation of faith through the practice of religious values in which all of these aimed at achieving victory in this world and the hereafter (al-falah). This is supported by the view of Muhd. Hunter (2012). He stated:

"In Islam, the individual's vision, mission and objektif is to achieve both succes in the world and hereafter. This is al-falah."

\footnotetext{
2 Muhd. Murray Hunter, School of Business Innovation and Technopreneurship, Universiti Malaya Perlis (UniMAP), Perlis.
} 
INTERNATIONAL JOURNAL OF ACADEMIC RESEARCH IN BUSINESS AND SOCIAL SCIENCES

Vol. 8, No. 10, Oct. 2018, E-ISSN: 2222-6990 ㄷ 2018 HRMARS

In agreement of Hunter (2012), Capra (1995) view that:

'The fulfillment of all these needs would make all members of both the present and the future generations tranquil, comfortable, healthy and efficient, and able to contribute richly towards the realization and perpetuation of falah and hayat tayyibah."

Based on this discussion, a few development scholars stated that al-falah is the ultimate objective of IBD.

\section{(b) Group That Says Mardat Allah}

The group that stated mardat Allah as the ultimate objective of IBD includes Salleh (2003), Abd Malik $(1999)^{3}$, al-Qaradawiy (1996), and Dusuki (2013).

According to Salleh (2003), the ultimate objective of IBD is to attain mardat Allah SWT. In the article Tujuh Prinsip Pembangunan Berteraskan Islam, he stated:

"Development is a means of achieving the mardat Allah. When the pleasure of Allah SWT is attained, al-falah, ie happiness in the world and happiness in the hereafter, will be bestowed. That is, happiness in the world and in the hereafter can only be achieved if Allah SWT pleases. For that reason, the ultimate objective of development is the pleasure of Allah SWT, not the happiness of the world and the hereafter."

His opinion is supported by Abdul Malik (1999). ${ }^{4}$ He stated that a ma'nawiyyah blessing in the form of the pleasure of Allah SWT is immense. The evidence is that all blessings in the form of mahsusah (paradise and its beauty) have no meaning without the pleasure of Allah. In order to prove this matter, he quoted Rabi'ah al-'Adawiyyah:

"For me, the pleasure of Allah is what I hope for. As for where I want to be placed, as long as there is the pleasure of Allah, I do not choose."

al-Qaradawiy (1996) stressed that for every Muslim, the basis of all activity is Allah. So, according to him, the objective of all activities should be towards Allah and attaining mardat Allah as well as ensuring that the implementation method is in accordance to what is sanctioned by Allah SWT. ${ }^{5}$

In the meantime, Dusuki (2013) also stated Mardat Allah as the ultimate objective in IBD. This is in accordance to the opinion of Aidit Ghazali (1990) who stated:

\footnotetext{
${ }^{3}$ HAMKA

${ }^{4}$ Excerpt from an article of Hanapi (2013:181).

5 Excerpt from an article of Ahmad (2010:288).
} 
INTERNATIONAL JOURNAL OF ACADEMIC RESEARCH IN BUSINESS AND SOCIAL SCIENCES Vol. 8, No. 10, Oct. 2018, E-ISSN: 2222-6990 @ 2018 HRMARS

"Necessities, facilities and well-being in life are simply tools to achieve the ultimate objective of Islam i.e. mardat Allah."

Table 1 shows different views of IBD scholars on the true ultimate objective of IBD. Based on Table 1, there are differences in opinions between a few IBD scholars. The ultimate objective according to the two groups of IBD scholars is either al-falah or mardat Allah.

Table 1. Different Views of Two Groups of Scholars in Development

\begin{tabular}{|c|c|}
\hline Al-falah & Mardat Allah \\
\hline $\begin{array}{l}\text { "Humans are expected to be able to } \\
\text { perform their duties well as a caliph of } \\
\text { Allah on earth because this responsibility } \\
\text { will be accountable for in the hereafter. It } \\
\text { is for this reason that the success of every } \\
\text { Muslim individual in implementing the } \\
\text { demands of economic life is to achieve al- } \\
\text { falah, the true success in this world and the } \\
\text { hereafter" (Salamon, 2009). }\end{array}$ & $\begin{array}{l}\text { "Necessities, facilities and well-being in life } \\
\text { are simply tools to achieve the ultimate } \\
\text { objective of Islam i.e. mardat Allah" (Ghazali, } \\
\text { 1990). }\end{array}$ \\
\hline $\begin{array}{l}\text { "'In Islam, the individual's vision, } \\
\text { mission and objektif is to achieve both } \\
\text { succes in the world and hereafter. This } \\
\text { is al-falah" (Hunter, 2012). }\end{array}$ & $\begin{array}{l}\text { "Al-Qaradawiy (1996) stressed that for every } \\
\text { Muslim, the basis of all activity is Allah. So, } \\
\text { according to him, the objective of all activities } \\
\text { should be towards Allah and attaining mardat } \\
\text { Allah as well as ensuring that the } \\
\text { implementation method is in accordance to } \\
\text { what is sanctioned by Allah SWT" (Ahmad, } \\
\text { 2010). }\end{array}$ \\
\hline $\begin{array}{l}\text { "The fulfillment of all these needs } \\
\text { would make all members of both the } \\
\text { present and the future generations } \\
\text { tranquil, comfortable, healthy and } \\
\text { efficient, and able to contribute } \\
\text { richly towards the realization and } \\
\text { perpetuation of falah and hayat } \\
\text { tayyibah" (Capra, 1995). }\end{array}$ & $\begin{array}{l}\text { "Development is a means of achieving the } \\
\text { mardat Allah. When the pleasure of Allah } \\
\text { SWT is attained, al-falah, ie happiness in } \\
\text { the world and happiness in the hereafter, } \\
\text { will be bestowed. That is, happiness in the } \\
\text { world and in the hereafter can only be } \\
\text { achieved if Allah SWT pleases. For that } \\
\text { reason, the ultimate objective of } \\
\text { development is the pleasure of Allah SWT, } \\
\text { not the happiness of the world and the } \\
\text { hereafter" (Salleh, 2003). }\end{array}$ \\
\hline
\end{tabular}

ANALYSIS OF THE ULTIMATE OBJECTIVE OF IBD: AL-FALAH AND MARDAT ALLAH

Al-falah is an Arabic word which means victory (Munawwir, 1984). In al-Qur'an, there are various verse that describe victory in the eyes of Allah. Among them include Allah's words; 
"Certainly will the believers have succeeded: They who are during their prayer humbly submissive" (Surah al-Mu'minun: 1-2).

"Indeed whosoever purifies himself (by avoiding polytheism and accepting Islamic Monotheism) shall achieve success" (Surah al-A'la: 14).

Based on the above verse it is understood that the measure of ultimate success in the world and in the hereafter is in obeying the command of Allah SWT. However, obeying the command of Allah SWT must be practiced in the manner shown by Prophet Muhammad ( (1) This concurs with the opinion of Jan (1996). According to him, human success in the world and in the hereafter lies in obeying the command of Allah SWT by following al-Sunnah (way of life) of Prophet Muhammad. Al-falah will not

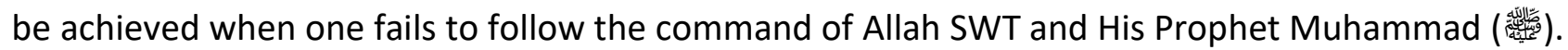

To support this discussion, the researcher refocused the story of the battle of Uhud when some

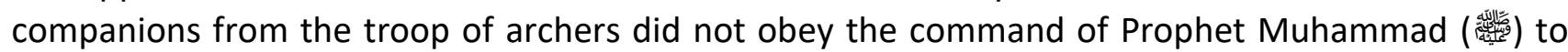
keep control of the hill of Uhud from the enemy. The archers were eventually attacked by the enemy as they went down the hill to pick up the spoils of war. The defeat was because they were not obedient to the command of the Prophet (pbuh) at that time.

According to Al-Kandahlawiy (1965) and Al-Kandahlawiy (1944) a mujahid named Quzman failed to attain the pleasure of Allah even though he killed nine mushrikin and died in the battle of Uhud. When found in the aftermath of the war, the companions discovered many severe wounds on his body. The Muslims then carried his body back to the settlement of Bani Dhufr. They gave him good tidings about the promise of Allah SWT in the form of heavenly reward. According to Al-Mubarakfuri (2008), the companions and fellow Muslims were disappointed when they found out that he had uttered:

"By Allah, I did not fight except for the dignity of my people. If it were not for this, I would not fight."

Afterwards he stabbed himself for the unbearable pain of severe injury he suffered. His actions were likened to suicide. The Prophet (peace and blessings of Allah be upon him) told the companions that Quzman is an inhabitant of hell. Although the victory (al-fawz) was in favor of the Muslims and Quzman fell in the battlefield, his death was not in the path of Allah SWT. So he was considered to fail in his struggle.

Meanwhile, Qarun and Tha'labah stories can also be used as indicators of actual success in development. According to Salleh (2000), Qarun, who lived in the era of prophet Musa a.s. had succeeded in generating abundance of wealth. However, he apparently became arrogant (takabbur), miserly, refused to give zakat, and rebelled against prophet Musa a.s. and Allah SWT after attaining success. In the end, Allah SWT wasn't pleased with his success in the form of his procured wealth and 
command the earth to swallow him and all his wealth. The same happened to a companion among

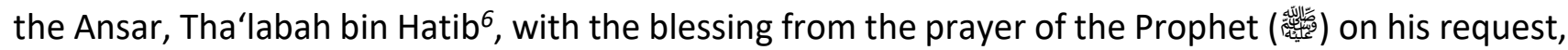
the goats he raised multiplied. However, he became negligent and disobedient by refusing the order to pay zakat by the amil appointed by the prophet (䊼). Zakat was regarded the same as jizyah by him. Although he succeeded with the wealth he obtained, Allah SWT wasn't pleased with his success. Hence, this development effort in the form of farming and wealth accumulation was considered a failure. This is documented in the Qur'an by the Words of Allah SWT:

"And among them are those who made a covenant with Allah, [saying], "If He should give us from His bounty, we will surely spend in charity, and we will surely be among the righteous. But when he gave them from His bounty, they were stingy with it and turned away while they refused. So He penalized them with hypocrisy in their hearts until the Day they will meet Him - because they failed Allah in what they promised Him and because they [habitually] used to lie" (Al-Taubah 9:75-77).

From the above analysis of the views of IBD figures, the outcome of success or failure in material or spiritual development is the absolute right of Allah SWT. Success (al-falah) does not necessarily be a true success in the eyes of Allah SWT. Success in this world does not mean success in the hereafter. It all depends on the pleasure of Allah (mardat Allah). According to Salleh (2003), Successful developments are developments which the developers are rewarded paradise by Allah SWT in the hereafter. If a person is punished with the hellfire, the development they achieved will not be considered a success no matter how many physical and material development they accomplished in this world. However, attaining paradise is not the ultimate objective of IBD. The absolute objective in IBD is to attain the pleasure of Allah. This is based on the Hadith of Rasulullah (綵):

"Narrated by Abu Sa'id al-Khudri r.a., Allah's Messenger ( (the people of Paradise, ' $\mathrm{O}$ the people of Paradise!' They will say, 'Labbaik, $\mathrm{O}$ our Lord, and Sa 'daik!' Allah will say, 'Are you pleased?" They will say, 'Why should we not be pleased since You have given us what You have not given to anyone of Your creation?' Allah will say, 'I will give you something better than that.' They will reply, 'O our Lord! And what is better than that?' Allah will say, 'I will bestow My pleasure and contentment upon you so that I will never be angry with you after for-ever.'" (Riwayat al-Bukhariy, no. Hadith: 6549, Ibn Hajar, 1989c: 506-507).

In clarifying the Hadith, Al-Asfahani (t.t.a) stated that the word ridwan was used specifically to show the highest pleasure of Allah. In his opinion, it was concluded that the pleasure of Allah can be divided to two types, i.e. small pleasure and huge pleasure. With the small pleasure of Allah, the people of

\footnotetext{
${ }^{6}$ Also known as Tha'labah bin Abi Hatib, from Bani Umayyah Bin Zaid. He died in the era of Khalifah 'Uthman Ghani r.a (Ruh al-Ma'ani Jild 9, 9-10: 455). Although Tha'labah who participated in the battle of Badr were named Tha'labah bin 'Amr bin 'Ubaid bin Mihsan alAnthari r.a, he died in the battle of Uhud. (Tahzib al-Kamal Jild. 2, No. 845: 171).
} 
paradise entered paradise, while the huge pleasure of Allah is ridwan that is bestowed to the people of paradise after they had obtain every other blessings from Allah.

In other words, when human obtained the reward of paradise with all its beauties such as flowing rivers, extensive gardens and tasty fruits, which then completed with the blessings in the form of the pleasure of Allah SWT, then it means that he had achieved the ultimate objective he fought for during his life in this world (Hanapi, 2013). Here, the ma'nawiyyah blessing (that can be felt in one's soul) and the mahsusah blessings (that can be felt physically) combined as one (Abdul malik, 1999).

\section{CONCLUSION}

From the above discussion, it can be concluded that the ultimate objective of IBD is to achieve Mardat Allah. This matter is elucidated by the Hadith narrated by Imam al-Bukhariy as discussed. If success in the form of entering paradise is the true ultimate objective of IBD, why would Allah SWT bestowed His pleasure after they are in paradise, enjoying all the luxury in the form of delicious food, flowing rivers, shady trees and all sorts of favours that have never been seen by the eyes and have never been heard by the ears before. It shows that the existence of the heavens cannot be said to be the highest and true gift of Allah SWT. Hence, this article concludes that the ultimate objective of IBD is to obtain the ultimate goal of development i.e. Mardat Allah SWT. While al-falah is the result of receiving Mardat Allah SWT.

\section{Acknowledgement}

This research was supported by the Center for Islamic Development Management Studies (ISDEV), Universiti Sains Malaysia, Pulau Pinang, Malaysia. Huge appreciation to Kamarul Ariffin Ithnan and Dr. Mohd Syakir Mohd Rosdi towards the realisation of this article. Kamarul Ariffin Bin Ithnan is a PhD candidate at Centre for Islamic Development Management Studies (ISDEV), Universiti Sains Malaysia, Pulau Pinang. Dr. Mohd Syakir Mohd Rosdi is a Senior Lecturer for the Center for Islamic Development Management Studies (ISDEV), Universiti Sains Malaysia.

\section{Corresponding Author}

Dr. Mohd Syakir Mohd Rosdi

Senior Lecturer

Center for Islamic Development Management Studies (ISDEV)

Universiti Sains Malaysia,

Penang, Malaysia.

Email: mohdsyakirmohdrosdi@gmail.com/mohdsyakir@usm.my

\section{References}

Abdullah, M. Y. (2013). Konsep etika dalam sistem pengurusan Islam. Sabah: Utusan Borneo, Rabu, 14 Ogos 2013. 
INTERNATIONAL JOURNAL OF ACADEMIC RESEARCH IN BUSINESS AND SOCIAL SCIENCES

Vol. 8, No. 10, Oct. 2018, E-ISSN: 2222-6990 @ 2018 HRMARS

Ahmad, F. A. (2010). Kaedah pengurusan institusi-institusi pembangunan berteraskan Islam di Malaysia. Selangor: Univision Press Sdn. Bhd.

Ahmad, K. (1994). Islamic approach to development - Some policy implications, Islamabad, Pakistan: Institute of policy studies.

Al-Asfahaniy, R. \& Muhammad, A. Q. H. (t.t.) Al-Mufradat fi gharib al-Qur'an. Jil. 1. Beirut, Lubnan: Dar al-Ma'fifah.

Amrullah, A. M. K. (HAMKA) (1999). Tafsir al-Azhar, Jil. 4. Singapura : Pustaka Nasional Pte. Ptd..

Chapra, M. U. (1995). Islam and the economic challenge (Islamic economics series, No. 17). Riyadh: International Islamic Publising House.

Chapra, M. U. (1996). Islam dan pembangunan ekonomi (Islam and economic development). Terjemahan Adi Setia Mohd Dom. Selangor: The international institute of Islamic thought (ISTAC), Malaysia dan Thinker's Library Sdn. Bhd.

Dusuki, A. W. (2013). Fleksibiliti uslub dakwah. Diakses dari http://kronikapemuda.blogspot.com/2013/08/syarahan-prof-dr-asyraf-wajdi-di-uiam. html. Pada 20 Mei 2015.

Hanapi, M. S. (2013). Tasawur Islam dan pembangunan: Kuala Lumpur: Dewan bahasa dan pustaka. Hasan, A. R (2011). Kamus: Bahasa Arab-Melayu. Bahasa Melayu- Arab. Selangor: Oxford Fajar Sdn. Bhd.

Hassan, M. K. (1990). "Pembangunan yang berteraskan Islam" dlm. Muhammad Syukri Salleh (Peny.). Konsep dan pelaksanaan pembangunan berteraskan Islam. Pulau Pinang: Penerbit Universiti Sains Malaysia.

Hunter, M. Murray (2012). International journal of business and technopreneurship, Vol. 2, No. 1, February 2012 (121-135).

Hussain, S. (2010). Kesejahteraan dan kedamaian melalui pembangunan modal insan: Kajian teks Hidayah al-Salikin; Seminar serantau Islam dan kesejahteraan sejagat, 24-25 Februari 2010, Universiti Islam Sultan Sharif Ali Brunei Darussalam.

Idris, K. A. (1996). Kontemporari Islam. Kuala Lumpur: Institut Kefahaman Islam Malaysia (IKIM).

Jamaluddin, Y.M. (654). Tahzib al-Kamal Fi Asma' al-Rijal: Lubnan: Risalah Publisers.

Jan, I. (1996). Zadu al-Da'ie. Lahore: Maktabah Sa'idiyyah.

Jerry D. Gray (2013). Deadly MIST. Selangor: PTS Islamika Sdn. Bhd.

Rosdi, M., M. S. (2014). Tahalluf siasi dalam ekonomi politik Islam: Satu kajian teoretis: Pulau Pinang: Pusat Kajian Pengurusan Pembangunan Islam (ISDEV) Universiti Sains Malaysia.

Rosdi,M., M. S. \& Mohd Razif, N. A. (2017). Uswah hasanah country of khalifah umar abdul aziz: an islamic political economy research. International Journal of Academic Research in Business and Social Sciences, Vol. 7, No. 6. DOI: 10.6007/IJARBSS/v7-i6/3026. URL: http://dx.doi.org/10.6007/IJARBSS/v7-i6/3026.

Rosdi,M., M. S. \& Mohd Razif, N. A. (2017). Uswah hasanah country of khalifah umar abdul aziz: an islamic political economy research. International Journal of Academic Research in Business and Social Sciences, Vol. 7, No. 6. DOI: 10.6007/IJARBSS/v7-i6/3026. URL: http://dx.doi.org/10.6007/IJARBSS/v7-i6/3026.

Rosdi,M., M. S. (2013). Ekonomi politik Islam: Teori dan falsafah. Kuala Lumpur: Dewan Bahasa dan Pustaka. 
INTERNATIONAL JOURNAL OF ACADEMIC RESEARCH IN BUSINESS AND SOCIAL SCIENCES

Vol. 8, No. 10, Oct. 2018, E-ISSN: 2222-6990 @ 2018 HRMARS

Rosdi,M., M. S. (2014a). “Mencari ekonomi holistik: Antara ekonomi Islam dan ekonomi politik Islam”, dlm. Internasional Pembangunan Islam I (KIPI-I). Universitas Jember, Indonesia.

Rosdi,M. M. S. (2014b). Islamic Political Economy: A Special Reference to the Use of Tahaluf Siyasi in the State of Kelantan, Malaysia. American International Journal of Contemporary Research, Vol. 4, No. 5, May 2014.

Rosdi,M., M. S. (2014c). Tahaluf siyasi dalam ekonomi politik Islam: Satu kajian teoretis. Thesis was submitted as a requirement for a PhD, Universiti Sains Malaysia.

Rosdi,M., M. S. (2015a). Conceptualization of Islamic Political Economy. American International Journal of Social Science, 4 (4), 71-77.

Rosdi,M., M. S. (2015b). Tahaluf Siyasi Dalam Ekonomi Politik Islam. Ekonomika: Jurnal Paradiqma Islam Di Bidang Keuangan, Ekonomi dan Pembangunan, 3 (1), 56-82.

Rosdi, M., M. S. (2015c). The Roles of Tahaluf Siyasi in Political Unity. International Journal of Humanities and Social Science, Vol. 5, No. 7, Julai.

Rosdi,M., M. S. (2015d). Ummah Economic Remedy: Between Islamic Economics and Islamic Political Economy. Journal of Business Management \& Economics, [S.I.], 4 (01), 38-46. DOI: http://dx.doi.org/10.15520/jbme.2016.vol4.iss01.169.pp38-46.

AlMarbawiy, M. I. (1955). Mukhtasar al-Tirmidhi wa Syarhihi bi Lughati al-Jawi al-Mal ayu alMusamma Bahr al-Madhi. Mesir: Dar al-Fikr.

AlKandahlawi, M. Y. dan Al-Kandahlawi, M. I. (1944). Hayatul al-Sahabah. Beirut: Dar al-Fikr.

Munawwar, A. W. (1984). Al Munawwar Kamus Arab - Indonesia. Surabaya: Penerbir Pustaka Progressif PO. Box 1322, Surabaya 6000.

Nik Hassan, N. M. (2014). Pandangan alam Islam dalam peradaban ekonomi. Selangor: IKIM

Othman, A. (2005). Kamus komprehensif Bahasa Melayu. Selangor: Oxford Fajar Sdn. Bhd.

Salamon, H. (2009). Perkembangan pasaran modal insan dalam pembangunan ekonomi negara. Jurnal Teknologi, 50 (E) Jun 2009: 1-9 @ Universiti Teknologi Malaysia.

Salleh, M. S. (2000). Pembangunan zaman Rasulullah ([?]): Antara kemiskinan dan kekayaan. Pulau Pinang: Pejabat mufti kerajaan negeri Pulau Pinang dan Projek Pengurusan Pembangunan Islam (IDMP), USM.

Salleh, M. S. (2002). Pembangunan Berteraskan Islam. Kuala Lumpur: Utusan Publication \& Disrtibutors Sdn. Bhd.

Salleh, M. S. (2003). Tujuh prinsip pembangunan berteraskan Islam: Pulau Pinang: Pusat Pengajian Pengurusan Pembangunan Islam, USM.

Salleh, M. S. (2009). "The philosophical foundations of Islamic Development: Khurshid Ahmad's Conception Revisited" dIm. Proceedings Langkawi Islamic Finance

Todaro, Michael P. (1977). Economic development in the third world. London: longman Group Limited.

Al-Qaradawiy, Y. (1996). Memahami keutamaan berasakan al-Qur'an dan-Sunnah. Petaling Jaya: Angkatan Belia Islam Malaysia. 